\title{
A DOUTRINA DE MAIO NA ARGENTINA ( $\left.{ }^{\star}\right)$.
}

\section{ENRIQUE DE GANDIA}

Já se afirmou muitas vêzes que a História é um tribunal. A História é o tribunal em que as últimas gerações julgam constantemente seus antepassados. Por isso o juízo da História muda com o tempo. À medida que os juízes acumulam mais elementos de julgamento as sentenças se modificam. A História sempre busca novas provas. O tempo é seu melhor aliado. História e tempo constituem a justiça inexorável. E' muito difícil fugir dessa justiça.

O 25 de maio é uma data que a História julga contìnuamente. Gerações de historiadores têm analisado seus menores detalhes, suas particularidades mais ocultas. O juízo dos anos tem mudado várias vêzes. Primeiro esta data foi encarada como o resultado de um choque de raças, depois acreditou-se que se tratasse do efeito de problemas comerciais; posteriormente foi considerada fruto de uma conspiração. Em tôdas as ocasiões julgaram que fôsse uma revolução local com alcance mais ou menos próximo.

A História dispunha de elementos preciosos, porém insuficientes. Os juízes, ou seja, os historiadores, imaginavam que a História argentina devia ser estudada dentro dos limites da nação; acreditavam, em sua ingênua conformidade, que 25 de maio era apenas uma data argentina. Mas novas descobertas começaram a descerrar os véus e a revelar-nos um 25 de maio de importância muito maior. $O$ ano de 1810 não está isolado na História argentina e na História do mundo. Começa por estar ligado à uma transformação profunda na História da humanidade. Esta data não pode ser estudada com o desconhecimento absurdo e total da História da América.

(*). - Texto em espanhol, traduzido pela Lic. Cecília de Lara, Instrutora da Cadeira de Língua Espanhola, Literatura Espanhola e Hispano-americana da Faculdade de Filosofia, Ciências e Letras da Universidade de Ş́o Paulo. (Nota da Redação). 
Podemos comprovar que as idéias no mundo estavam divididas em dois campos imensos e opostos: havia homens que defendiam os direitos naturais e a liberdade e outros que negavam êstes direitos e a liberdade. O fantasma da Revolução Francesa, que noutros tempos servia para solucionar todos os problemas históricos e explicar todos os avanços da humanidade, apresentou-se como uma convulsão espantosa e muito restrita; sem influências, sem admirações, limitada à França, combatida e odiada pelos próprios franceses e pela maior parte dos agitadores que haviam participado dela. Desaparecida esta funesta revolução, famosa apenas por seus crimes e seus excessos, foi preciso procurar as causas reais das profundas modificações que o mundo experimentou e estas começaram a ser encontradas no que sempre existira e ninguém soubera ver ou não quisera confessar.

Os povos do Ocidente, cristãos e católicos, viviam sôbre a base espiritual do grande princípio da liberdade do homem, de sua auto-determinação e de sua responsabilidade. Era a tradição da Grécia, de Roma e de Cristo que se prolongava na Europa de Carlos Magno, de Santo Tomás e dos teólogos de Salamanca: todo um mundo espiritual alicerçado no direito natural e na dignidade do homem. Por isso Carlos V autorizou os povos do Rio da Prata e do Paraguai a elegerem por si mesmos seus governadores em caso de morte ou ausência dos nomeados. Por isso os comuneros de Assunção lutaram pelo direito de colocar e destituir suas autoridades. Por isso o vice-rei Sobre Monte foi substituido por Liniers e por isso em maio, quando souberam que a Espanha estava perdida pensaram no regime das juntas, no govêrno do povo pelo povo, como única solução para não cair nas mãos do imperador dos franceses, que dominava meia Europa; da Grã-Bretanha, que ambicionava estender suas rêdes sôbre o mundo de Colombo; ou de Portugal, que contava com a irmã de Fernando VII, mulher do regente radicado no Brasil.

Estêve em moda, ùltimamente, falar dos ideais e da doutrina jurídica dos fatos de maio. Os estudiosos compreenderam que o grande problema da independência argentina é exclusivamente político. Por essa razão tantos livros e tantos autores perderam a atualidade. $\mathrm{O}$ drama da origem da nação argentina deve ser visto com critérios nem sequer imaginados em outras épocas. Foi muito comum, por exemplo, no período da história heróica argentina, falar de Francisco de Miranda como de um aventureiro, tipo Casanova, que tinha enamorado a imperatriz da Rússia Catarina II, a Grande, e obtido dela uma estranha proteção. Também se apresentava o favorito de Catarina, o extraordinário Gregório Alejandrovich Potemkim como um 
adulador vulgar. Atualmente a História das idéias políticas descobre nesses supostos romances, graves intrigas internacionais. A sensual Catarina não estava interessada nas boas maneiras do gentil Miranda, mas em conquistar as costas americanas do Oceano Pacífico. O projeto tinha sido proposto ao czar Pedro I por um aventureiro holandês. O Czar Pedro I não soube avaliar as grandiosas consequiências provenientes da penetração russa desde a Sibéria até as terras americanas do noroeste. Caçadores e comerciantes de peles estendiam há longo tempo a expansão russa até a América. A Califórnia era o objetivo mais cobiçado.

Os espanhóis tinham se estabelecido em San Diego e Monterrey em 1769, para impedir a ocupação russa. Quando Francisco de Miranda chegou a São Petersburgo em 1787 a imperatriz Catarina estava empenhada, desde o ano anterior, em mandar navios de guerra às terras da América, que ela supunha descobertas por navegadores russos. Miranda não foi atendido por razões sentimentais, mas por interêsses políticos. Podia ser enviado ao Pacífico, numa expedição russa ou a outra parte da América, para sublevar os americanos. Além disso, Catarina tinha se unido à Áustria para expulsar os turcos da Europa. A Espanha era, então, aliada da Turquia, assim como a Inglaterra, a Prússia e a França. Miranda, hispano-americano rebelde, conhecedor dos problemas políticos do Nôvo Mundo, era um elemento precioso para a ambiciosa imperatriz. A guerra russo-turca, que começou em agôsto de 1787, e a segunda frente aberta pela guerra russo-sueca, tornaram impossível uma ajuda russa a um conspirador como Miranda. Por outro lado, êste cometeu o êrro, em 1792, de participar da revolução francesa, incorporando-se ao exército republicano. Catarina II abandonou para sempre seus sonhos da América (1) . Aquilo que se julgou um romance foi algo completamente diferente.

Na Argentina não houve idéias de independência na ocasião em que tantos autores supuseram que tivessem existido. Quando foi celebrado o Cabildo aberto de 22 de maio de 1810 , antes das votações, todos os presentes cogitaram da possibilidade de considerar-se a independência da Espanha. Ninguém a queria, já que muito poucos a pediram na grande Assembléia de 1813. A independência, nos primeiros tempos, não era um fim, como julgaram tantos historiadores.

No máximo podia chegar a ser um meio para alcançar o que todos desejavam: uma reforma do reino e o govêrno do povo pelo próprio povo e não pelo mandato de reis absolutos.

(1). - Veja-se o interessante estudo de V. Miroshovski, Catalina II y Francisco de Miranda, no Boletin de la Academia Nacional de la História, Caracas, enero-marzo de 1958, tomo XLI, núm. 161. 
Esste ideal não era o resultado da Revolução Francesa. Hoje em dia nenhum estudioso sério acredita nas influências daquela criminosa revolução. Sua repercussão foi insignificante. Até o próprio Miranda, vítima dela, chegou a odiá-la. Os ideais populistas e democráticos do povo espanhol ou hispano-americano tinham origens muito remotas. Gregório de Tours, no século VI, santo justamente chamado pai da historiografia francesa, declarava que os visigodos

\footnotetext{
"habian tomado este detestable hábito: cuando sus reyes no les gustaban, los asaltaban a mano armado y elegian en su lugar al que les convenía" (2).
}

Este tiranicídio, praticado pelos visigodos, era a tradição romana que continuava pujante através dos séculos. A lembrança de César apunhalado por Bruto não se extinguira. E foi admitido por Santo Tomás, pelos escolásticos e teólogos jesuítas, desde Juan de Mariana até Francisco Suarez. Foi também a fagulha que incendiou a História hispano-americana. No Paraguai, Alvar Nuñez foi derrubado pelos comuneros de Irala. Outros comuneros, no início do século XVIII, com Antequera e Mompó, combateram mais de 20 anos pelo direito do povo de pôr e de destituir o governador. Em 1806, o povo de Buenos Aires arrebata o comando das tropas das mãos de Sobre Montes e entrega-o a Liniers, e no ano seguinte destitui o vice-rei e elege Liniers. Este povo, ao qual se tentou arrancar o mérito de ter resolvido seu destino, é o mesmo que se levantou contra Napoleão a 2 de maio de 1808, em Madrí e aclamou Fernando VII, em tôda a América, quando soube que estava a ponto de perder a Espanha. O entusiasmo que o povo de Buenos Aires sentia por seu rei cativo era tão grande que em 1808, quando José Manuel de Goyenache chegou a esta cidade, as ruas se iluminaram de noite e o povo em tropel saía com as músicas dos regimentos. Homens, mulheres e crianças levavam o retrato de Fernando como divisa:

"y algunos hombres hasta con cuatro caminaban, uno por delante, otro por detrás, y uno a cada lado, para que de cualquier parte que fuese mirado se viera a su majestad".

A artilharia corria pelas ruas, lançando tiros de pólvora e no canhão de vanguarda ia montado um cônego da Catedral de Córdova. Manuel Arroyo, autor dêste relato e testemunha dos fatos, recorda-se

\footnotetext{
(2). - José Luiz Romero, Sociedad y cultura en la temprana edad media, na Revista Histórica de la Universiáad, Montevidéo, 1959.

(3). - Museo Mitre, Documentos del Archivo de Pueyrredón, Buenos Aires, 1912, tomo I.
} 
de que na praça acendiam fogos e os participantes da assembléia distribuíam ao povo jarros de vinho

"y yo, por la primera vez en mi vida, ví empelucados con espadín, ébrios por las calles..." (3).

Outra testemunha daqueles momentos, o capelão José de Reyna, numa carta a seu tio, o marechal de campo Tomás Reyna, datada de 10 de setembro de $1808 \mathrm{diz}$ que mal ouviram as notícias trazidas por Goyenacho.

"al momento empezaran a verse en los sombreros escarapelas encarnadas hasta en los clérigos, frailes y mujeres formadas de un pedazo de grana con una $\mathrm{F}$ y un número 7 . En aquellas pocas horas hasta la noche se dispusieron infinidad de cuadrillas con músicas y mogigangas muy graciosas... Se oían cosas muy chistosas por los que componían las cuadrillas. Entre estas andaba una que en cada esquina tocaba una campanilla y decía: Para el entierro de Napolón y Soledad de Godoy. Así se pasó toda aquella noche que no se ó́an sino músicas, repiques de campanas, cañonazos, fuegos artificiales, vivas a Fernando Séptimo y a la nación española y dicterios a Napoleón y a todos sus secuaces (4).

Esse povo, fanático por Fernando VII, foi o que fêz os dias de maio, o mesmo povo que uma escola de historiadores, envenenados por uma falsa tradição, apresentou usando uma máscara de Fernando VII, fingido e perjuro em grau inacreditável.

Atualmente sabemos que Cisneros deu a idéia de uma reunião, para tomar decisões, em sua proclamação de 18 de maio de 1810 . A Espanha estava perdida. Era preciso resolver o destino da América. Cisneros incitou a resolvê-lo (5). E o povo se reuniu na famosa Assembléia de 22 de maio. Esta Assembléia marca o comêço da história nacional argentina, não mais interrompida até hoje. Foram convidados 450 habitantes. Compareceram 251. Antes de proceder-se à votação houve demoradas discussões. A gente alí reunida trocava idéias. Os historiadores, baseados nas recordações pessoais de alguns contemporâneos dos fatos, preferiram falar dessas discussões, tão pouco conhecidas, em vez de se referirem aos votos. As atas da Assembléia, embora utilizadas desde há muito, foram reimpressas oficialmente em 1927; mas desde êsse ano não foram muitas

\footnotetext{
(4). - Julio César González, Como se preparó el supuesto afrancesamiento y la actitud juntista del Comisionado de la Junta Suprema de España e Inatas, don José Manuel de Goyenacho, en Academia Nacional de la Historia, Tercer Congreso Internacional de Historia de América, Buenos Aires, 1961; tomo II.

(5) . - Veja-se nossa Historia del 25 de Mayo, Buenos Aires, 1960.
} 
as obras históricas que as analisaram. Por essa razão repetem-se ainda tantos erros e contam-se tantas fábulas. A mais corrente ế a que afirma que o bispo D. Benito de la Lue y Riega sustentou que enquanto existisse

"un solo español en la Península libre de la dominación francesa constituía la nación".

Isto afirmou Francisco Saguí em Los últimos cuatro años de la dominación española en el antiguo Virreinato del Río de la Plata, obra que contém verdades admiráveis e também tradições duvidosas, escritas depois dos acontecimentos e impressa em Buenos Aires em 1874. Outra testemunha daqueles momentos, anônima, informou que o bispo

"concluyó con que aunque ubiese quedado un solo vocal de la Junta Central y arribase a nuestras playas, lo deberiamos recibir como a la Soberanía".

Roberto H. Marfany faz notar, muito bem, que Saguí pode ter confundido, em suas recordações, a idéia de um só

"vocal de la Junta Central" com "un sólo español".

O bispo jamais poderia ter dito semelhante insensatez. A mesma confusão fêz Corbelio de Saavedra, uns vinte anos depois dos fatos. Segundo êle, o bispo disse

"que no solamente no había por que hacer novedad con el virrey, sino que aún cuando no quedase parte alguna de la España que no estuviese subyugada, los españoles que se encontrasen en las Américas debían tomar y reasumir el mando de ellas, y que ésto sólo podría venir a manos de los hijos del país quando ya no hubiese quedado un solo español en él".

Estas lembranças se concretizaram na versão de Vicente Fidel López, que, em sua clássica História, falou que o bispo defendeu a tese de

"que mientras quedara un punto libre de la España en donde se defendiera la causa del rey cautivo, aunque no fuese más que un pedazo de tierra o una aldea, ese pedazo de tierra o esa aldea, por pequeña que fuera, tenía el derecho innegable de tomar el nombre del Soberano para crear un gobierno provisional y para nombrar o autorizar todos los empleados y virreyes que debian gobernar las colonias...".

Tinha acrescentado que 


\begin{abstract}
"dado el caso de que toda la Península cayese en poder de los malditos franceses, los españoles que en América estuviesen constituidos en dignidad por sus empleos civiles y eclesiásticos, eran los únicos que tenían derecho a concertarse para erigir el gobierno que debía conservar estos domínios a S. M. Fernando VII o a sus sucessores...".
\end{abstract}

Bartolomeu Mitre, na sua famosa História de Belgrano repetiu que o bispo declarou

\begin{abstract}
"que mientras existiera en España un pedazo de tierra mandado por españoles, eso pedazo de tierra debía mandar en las Américas; y que, mientras existiera un solo español a las Américas, ese español debía mandar a los americanos, pudiendo sólo venir el mando a los hijos del país cuando ya no hubiese un solo español en él".
\end{abstract}

A lenda do discurso do bispo teve uma longa trajetória e é ainda repetida pelas crianças nas escolas e pelos oradores nas tribunas. Outra testemunha daquela ocasião Nicolás de Vedis parece ignorá-la e dá uma versão exata das palavras do pobre bispo: Exortou

"la paz, que nadie daba muestras de alterar, y a permanecer en el estado que se hallaban las cosas, que era lo que a su ilustrísima le venía mejor".

Este final foi acrescentado por Vedis, pois sua ilustríssima continuava à frente de seu bispado em qualquer govêrno, como tinha permanecido durante o domínio dos inglêses. E' possível que Vedis tenha confundido as palavras ditas enquanto se aguardava a hora da votação com o próprio voto. A história não tem outro caminho para conhecer com exatidão o pensamento do bispo, a não ser a leitura do seu próprio voto assinado; e êste é muito diferente do que conta a lenda e muito parecido com o que disse um homem ponderado como o general Vedis. Com efeito, consta na ata que D. Benito limitou-se a afirmar que

"es de dictamen que el Excelentísimo Señor Virrey continúe en el ejercicio de sus funciones sin más novedad que la de ser asociado para ellas del señor Regente y del señor Oidor de la Real Audiencia".

E' possível que o voto tenha sido diferente das discussões e conversações anteriores à votação. $E^{\prime}$ inegável que não há nenhuma prova de que o bispo tenha dito o que a tradição tão falsamente lhe atribuiu. 
Contam algumas testemunhas dos fatos que o doutor Juan José Castelli foi incitado a replicar ao bispo. O general Nicolás de Vedis recorda-se de que Castelli começou a falar um pouco hesitante; mas logo

"con la profusión de la verba que le era genial, bien que las objeciones que se le opusieron por parte de uno de los oidores, que creo fue Villota, lo embarazaron tanto que para sacarlo del círculo de la controversia, tomó a su cargo la causa del pueblo el benemérito y elocuente abogado don Juan José Paso... Probó Paso a la evidencia que en la ausencia involuntaria del monarca estaban habilitados los pueblos a reasumir la autoridad soberana y a elegir el gobierno que creyeren más adecuado en favor de los derechos del rey".

De acôrdo com Francisco Saguí, Castelli declarou que

"la España ha caducado en su poder para con estos países; sosteniendo con autores y princípios que el pueblo de esta capital debía asumir el poder majestas o los derechos de la soberanía, y formar, en consecuencia, un gobierno de su confianza que vigilase por su seguridad, ya que no lo podía hacer la nación española por su afligente estado".

\section{A réplica do fiscal Don Manuel Genaro Villota negou que}

"el pueblo de Buenos Aires sólo tuviese ese derecho; que no era él más que uno de los muchos del virreinato, de modo que solamente después de oídos todos, y en vista de su conformidad, podría ser formado ese gobierno legítimamente".

Castelli ficou desconcertado. Paso tomou a defesa e explicou quão difícil era consultar os outros povos do vice-reinado e que

"Buenos Aires necesitaba con mucha urgencia ponerse a cubierto de los peligros que la amenazan, por el poder de la Francia y el triste estado de la península. Para ello, una de las primeras medidas debe ser la inmediata formación de una Junta provisoria de gobierno a nombre del señor don Fernando VII, y que ella proceda sin demora a invitar a los demás pueblos del virreinato a que concurran por sus representantes a la formación del gobierno permanente".

Os ouvidores expulsos de Buenos Aires a 22 de junho de 1810 deram uma versão mais precisa dêstes discursos, com maior número de pormenores que concidem em geral com as linhas expostas por Saguí e por Vedis, que dizem: 
"El doctor Castelli, orador destinado para alucinar a los concurrentes, puso empeño en demostrar que desde que el señor infante don Antonio había salido de Madrid, había caducado el gobierno soberano de España; que ahora con mayor razón debía considerarse haber expirado con la disolución de la Junta Central, porque además de haber sido acusado de infidencia por el pueblo de su villa, no tenía facultades para el establecimiento del supremo gobierno de Regencia, ya porque los poderes de sus vocales eran personalísimos para el gobierno y no podían delegarse, y ya por falta de concurrencia de los diputados de América en la elección y establecimento de aquel gobierno, deduciendo de aquí su ilegitimidad y la reversión de los derechos de la soberanía al pueblo de Buenos Aires y su libre ejercício en la instalación de un nuevo gobierno, principlamente no existiendo ya como se suponía no existir la España en la dominación del señor don Fernando VII. El Fiscal de lo civil se vió precisado a rebatir los errores del doctor Castelli sosteniendo que en las circunstancias de apuro en que se hizo el nombramiento de la Regencia, sólo en la Junta Central podían reunirse los votos de todas las provincias y la facultad para la elección; que cualquiera defecto que se pudiera notar en ésta lo subsonaba el reconocimiento posterior de los pueblos; que el de Buenus Aires no tenían por sí sólo derecho alguno a decidir sobre la legitimidad del gobierno de Regencia sino en unión con toda la Representación nacional y mucho menos a elegirse un gobierno soberano, que seria lo mismo que romper la unidad de la nación y establecer en ella tantas soberanías como pueblos...".

Como vemos, nesta informação datada de 7 de setembro de 1810 , em Las Palmas, os ouvidores expõem o pensamento de Castelli e do fiscal Villota. Não dizem uma palavra sôbre Paso.

$\mathrm{E}^{\prime}$ inegável que tôdas as testemunhas coincidem em certos pontos e diferem noutros. São os crioulos, anos depois dos acontecimentos, que se lembram de Paso. Até Saavedra, em suas memórias escritas umas duas décadas depois, diz que

"los doctores don Juan José Paso y don Juan José Castelli, irritados de él y del aire grave con que el obispo lo produjo, tomaron la palabra para rebatirlo".

Ricardo Zorraquín Becú (6), fêz uma observação sutil. Quando Castelli defendeu o médico Diego Paroissier, prêso por denúncia da infanta Carlota em Montevidéu, sustentou que as juntas espanholas tinham se formado

"sin tener para ello ni la deliberación especial del rey tan necesaria... ni la presunta de su voluntad o la ley de la constituición,

(6). - La doctrina juridica de la revolución de Mayo, em Revista del Instituto de Historia del Derecho, Buenos Aires, 1960, núm. 11. 
no habiendo, como no hay, pacto específico o tácito de reservación de la nación".

O doutor Zorraquín Becú disse:

"Estas últimas palabras parecen indicar que en 1809 Castelli por táctica forense o por convicción momentánea - no creía en la teoría que iba a sostener en 1810, es decir, en "la reversión de los derechos de la soberanía al pueblo de Buenos Aires" por ausencia del monarca. Si no había "pacto específico o tácito de reservación en la nación", Ia autoridad no podía nunca dejar de estar unida a la persona del monarca. $Y$ la falta de éste sin dejar sucessor o representante no permitía realizar ninguna acción legítima para reemplazarlo".

Outro investigador dêstes problemas, o $\mathrm{Dr}$. Roberto H. Marfany (7), não vê esta mudança de opinião ou de doutrina. O que se passou foi muito simples: Castelli, em 1809, expunha a mais pura doutrina do jesuíta Francisco Suárez. Este, como já explicamos em não poucas páginas, afirmou sempre que o povo entrega ao soberano o poder que recebeu de Deus e que, se não existe um pacto, ou documento em que se faça constar sua devolução ao povo ou a quem fôr, o governante recebe êsse poder como uma doação sem estar obrigado, em nenhum momento, a devolver êsse poder ao povo, por nenhuma razão. Os "suaristas", que não se resignam a confessar que Suárez foi um defensor do absolutismo de origem popular e não divino, negam esta exata explicação do pensamento suarista, bem clara e indiscutível em seus escritos. Mas a verdade para quem analisar imparcialmente os textos de Suárez, é a que expusemos. Castelli era suarista em 1809 e deixou de sê-lo em 1810. Tornou-se tomista, entrou na corrente defendida por todos os homens que decidiram o Cabildo de 22 de maio e que vinha agitando o povo de Buenos Aires e do vice-reinado desde o alto Perú. Com efeito, em 1809 um anônimo do alto Perú explicou num extenso documento ao governador Francisco Javier de Elío que era preciso realizar um grande Congresso, ou Côrtes ou, Junta com representantes de todo o vice-reinado para resolver a forma de govêrno porque

"Ias naciones no son haciendas ni herencias de los reyes, sino que antes, cual pueblo israelítico, son las que han la jurisdicción al rey para que la ejerza mientras el pueblo, como pueblo de Dios, no le contradice, como porque el orden de la obligación exige primero por Dios que la Patria, primero por la Patria que el Rey" (8).

(7). - El Cabildo de Mayo, em Genealogia. Hombres de Mayo - Revista del Instituto Argentino de Ciencias Genealógicas, Buenos Aires, 1961.

(8) . - Veja-se nosso livro La revisión de la historia argentina, Buenos Aires, 1952. 
Aquêles que, por patriotismo ou divergência pessoais conosco quiseram apresentar Castelli e Paso como autores da doutrina jurídica de maio só demonstraram ignorar tudo o que descobrimos e expusemos em vários livros nossos. O pensamento da reversão do poder do rei ao povo era tão antigo como a História da Espanha e constituía o fundamento, não só de tôda escolástica, exceptuando-se o absolutismo de Suárez, mas de políticos de Buenos Aires como o Dr. Benito González de Rivadavia, Martin de Alzaga e grande número de defensores desta doutrina no Cabildo aberto de 22. Mas agora devemos procurar o autor da fórmula de maio, saber se ela nasceu das discussões dos advogados Castelli e Paso, como afirma tôda uma tradição que encontra defensores também na atualidade, ou tem outro autor, não mencionado ou reconhecido pelos estudiosos que mais se aprofundaram nestes problemas. Acreditamos ter aclarado êste ponto em nossa Historia del 25 de Mayo. No entanto, convém esclarecer alguns detalhes. $E$ ' o próprio vice-rei $D$. Baltasar Hidalgo de Cisneros que começa por dar-nos uma visão exata do grande debate de 28 de maio. E' preciso levar em consideração suas palavras. Diz:

\footnotetext{
"Prestó su voto el Muy Reverendo Obispo de esta diócesis, don Benito Lue, fiel servidor de V. M., pero, a pesar de su recta intención, dió al exprenarlo ocasión a la suspicacia del doctor don Juan Castelli, principal interesado en la novedad, para que, al rebatirle varias proposiciones, viniese a fijar el punto que deseaba, cual era el de examinar si debia ya cesar en el gobierno superior y reasumirlo el Cabildo. Siguió el general don Pascual Ruiz Huidobro que, más atento a su ambición que al servicio de S. M. y contando con que depuesto el legítimo virrey recaería en él el mando como oficial de mayor gradación, dijo abiertamente que debía yo ser separado del Gobierno Superior por haber caducado en España la representación soberana que me nombró; que debía el Cabildo reasumirlo y depositarlo en otra persona de su confianza, y al concluir recibió el débil aplauso do que le victoriasen y dijesen alabanzas, tanto los partidarios que asistian al congreso, como las gentes que con estudios habían introducido a la plaza".
}

As palavras do vice-rei Cisneros destituído como presidente da Primeira Junta, são reveladoras de fatos que os historiadores, em geral, preferiram manter no esquecimento. Referem-se às discussões ou debates anteriores à votação. Prova-o o fato de mencionar o discurso de Castelli depois do que foi pronunciado pelo bispo. Não diz que Don Benito de La Lue y Ricga tenha dito os disparates que lhe atribui uma tradição lendária. Lembra-se de que Castelli levantou o problema de que se o vice-rei devia continuar com o poder ou 
se a Junta devia reassumí-lo, o que coincide com muitos outros testemunhos, em realidade com todos, e diz o que calam os historiadores modernos (alguns até chegam a cortar as palavras de Cisneros em suas transcrições quando começa a dizer: "siguió el general Don Pascual Ruiz Huidobro...". Com efeito: revela-nos que o terceiro a tomar a palavra na grande discussão anterior à votação foi Ruiz Huidobro e que foi êle quem deu a fórmula de maio, "abiertamente". A fórmula consistia em afastar o vice-rei do poder, por não existir na Espanha autoridade que o havia nomeado. O Cabildo devia reassumir êsse poder e depositá-lo em mãos de outra pessoa de sua confiança. Também o ex-vice-rei nos revela que as palavras de Ruiz Huidobro foram as únicas que receberam aplausos e louvores e que foi aclamado, tanto pelas pessoas que se achavam no Cabildo como pelas que se encontravam na praça. Esta homenagem tributada a Ruiz Huidobro foi única e não se repetiu com nenhum dos outros homens que, a 22 de maio, decidiram o futuro da história argentina.

Ruiz Huidobro foi, sem dúvida alguma, o orador que resolveu o destino do Cabildo, o homem. como reconheceu a Assembléia de 1815 , ao conceder uma pensão à sua viúva, que tornou possível o 25 de maio e que deu a verdadeira fórmula dêsse dia imorredouro na história da nação. Sabemos, também agora pelas atas indiscutíveis da Junta, que quando se passou à votação o primeiro a emitir seu voto foi o bispo Don Benito de La Lue y Riega e que o segundo já não foi Castelli nem outro, mas Ruiz Huidobro. Seu voto coincide perfeitamente com as idéias que expôs na reunião prévia, como afirmou o vice-rei Cisneros. Vejamos o que diz:

\footnotetext{
"Que debía cesar la autoridad del Excelentisimo Señor Virrey y reasumirla el Excelentísimo Cabildo, como representante del pueblo para ejercerla interin forme un gobierno provisorio dependiente de la legítima representación que haya en la Península de la Soberanía de nuestro augusto y amado monarca el señor don Fernando VII...".
}

Ou seja, com palavras atuais, que o vice-rei devia deixar o poder e que a Junta devia reassumir sua autoridade, como representante do povo, para exercê-la quando entregasse êsse poder a outra autoridade.

Pois bem: poder-se-ia supor que êsste voto de Ruiz Huidobro inspirou-se no que disse Castelli ou Paso, que foi só uma repetição de suas fórmulas ou palavras. Antes de mais nada, consta-nos, segundo o próprio ex-vice-rei, que as palavras de Ruiz Huidobro foram as únicas que receberam grandes aplausos na Junta e na praça e que foram elas que decidiram o fim do seu poder. Mas há algo mais: foi 
o próprio Ruiz Huidobro que se encarregou, em seu voto transcrito, de acrescentar e especificar qua havia expôsto isso mesmo antes:

"... fundando esta opinión en los datos que de palabra he manifestado al Excelentísimo Cabildo".

Isto é, Ruiz Huidobro, como êle próprio afirma e o vice-rei atesta, tinha explicado à Junta, antes, qual devia ser a fórmula, a doutrina jurídica daqueles momentos. Os autores de outras épocas, por razões que desconhecemos, esqueceram-se do nome de Ruiz Huidobro, autor da doutrina jurídica de maio; mas a história desenterra os mortos e exibe ao grande juiz, que é o público, a verdade resplandescente ou indiscutível.

A votação de 22 de maio, continuou avançando até que chegou a vêz de falar o grande amigo de Martín de Alzaga, Simón Rexas. Este se pronunciou a favor da permanência do vice-rei mas esclareceu que se o vice-rei fôsse destituído, o Cabildo devia nomear uma "Junta de habitantes". O voto de Ruiz Huidobro, para que se destituísse o vice-rei, se tomasse o poder e o entregasse à uma entidade e a idéia de uma Junta de habitantes proposta por Rexas, deram a solução definitiva no Cabildo de 22 de maio. Tudo quanto se queira arguir em contrário se desmorona diante destas provas indiscutíveis.

O resultado da votação foi exatamente aquêle proposto por Ruiz, Huidobro e por Rexas. Diz a ata do Cabildo que:

\footnotetext{
"hecha la regulación con el más prolijo examen, resulta de ella a pluralidad con exceso que el Excelentísimo Señor Virrey debe cesar en el mando y recaer éste provisionalmente en el Excelentísimo Cabildo con voto decisivo al caballero Síndico procurador general hasta la erección de una Junta que ha de formar el mismo Excelentísimo Cabildo en la manera que estime conveniente".
}

Isto é, o povo reunido na Assembléia de 22 de maio tinha feito suas "a pluralidad con exceso" as idéias de Ruiz Huidobro, que o vice-rei devia deixar o poder e que êste recairía provisòriamente na Junta, e de Simón Rexas.

"hasta la erección de una Junta".

Os outros votantes tinham dado ao Cabildo plena autorização para que constituísse uma Junta

"en la manera que estime conveniente".

E' preciso revelar que esta autorização ao Cabildo para que formasse a Junta com os homens que mais the conviessem, não foi 
proposta por nenhum dos partidários de Alzaga nem por Ruiz Huidobro ou qualquer outro, mas por Cornélio de Saavedra num voto depois de Rexas, no qual fêz sua a idéia de uma Junta exposta por Rexas e glosou o voto de Ruiz Huidobro, adicionando apenas, por sua própria conta, que a formação de

\section{"la corporación o Junta... debe ser en el modo y forma que se estime por el Excelentisimo Cabildo".}

Tôdas as outras palavras dêle são repetição ou glosa do que tinha sido expôsto anteriormente. Devemos deter-nos nêstes detalhes porque uma escola de aduladores tergiversou a história atribuindo a Saavedra, por exemplo, nêste caso, idéias ou iniciativas que nunca teve, que pertencem a outras pessoas e que êle repetiu como tantos outros participantes da Assembléia.

A Assembléia não formou a Junta por si mesma. Consta, segundo várias testemunhas, que o síndico Julián de Leiva consultou Juán José Castelli e Manuel Belgrano. Foi assim que a primeira Junta, por convênio dos participantes da Assembléia, Castelli e Belgrano, foi presidida pelo ex vice-rei Cisneros, que tinha sido despojado de seu título; por outro espanhol, que aparece sempre em plano secundário, o comerciante José Santos de Inchaurregui, e três crioulos: o sacerdote Juán Nepomuceno de Sola, o advogado Castelli e o comandante Saavedra. Os três crioulos, na Assembléia, tinham votado pela deposição do vice-rei; mas sabemos, pelo general Enrique Martínez, capitão em 1810, que Saavedra

"se puso de acuerdo con ellos",

com os membros do Cabildo, e que, graças a essa intriga, passou a fazer parte da Primeira Junta. Por alguma razão Saavedra tinha pedido que se autorizasse ao Cabildo a formar a Junta, bildo".

"en el modo y forma que se estime por el Excelentísimo Ca-

Belgrano ficou fora da Junta. Isto o indignou. E' notório que na noite de 24 de maio êle e outros próceres andaram pelos quartéis para afastar de Saavedra a corporação de Patrícios. Isto nos conta Enrique Martinez, capitão nessa época. Outra testemunha daqueles momentos, e ator em muitos instantes, o general don Juán Ramón Belcarco, relembra que os descontentes estiveram a ponto de prender os principais chefes militares

Quais eram êstes descontentes? Constituíam dois grupos: o primeiro, formado pelos maçons que tinham ficado fora da Primeira 
Junta; o segundo, pelos anti-maçons que também queriam entrar neIa. Entre os primeiros se achavam Belgrano, Vieytes, Rodríguez Peña e outros. Entre os outros estavam os homens de Alzaga, como o doutor Mariano Moreno, o presbítero Alberti, Azcuenaga, Matheo e outros. Já relatamos em outras ocasiões o que se passou (9). Por fim chegaram a um acôrdo. O povo, movido pelos políticos de um partido e de outro, um povo constituído de gente humilde, exigiu respeitosamente, em papel selado, uma segunda Junta, sem o ex-vice-rei Cisneros, na qual deviam entrar outras pessoas. O Cabildo, diante da afluência popular, aprovou a lista que lhe foi apresentada e a Segunda Junta, presidida por Saavedra, começou a governar em 25 de maio de 1810 .

As finalidades da Segunda Junta de Maio eram grandes e nobres. Em primeiro lugar era preciso salvar as terras americanas de possíveis ataques franceses (10). Em segundo lugar deviam impedir que a infanta Carlota Joaquina se apoderasse destas regiões como rainha da América Espanhola e irmã de Fernando VII. Em terceiro lugar devia ser convocado um grande Congresso, idéia defendida principalmente por Martín de Alzaga e repetida por políticos anônimos do Alto Perú. Em quarto lugar êste Congresso deveria aprovar uma Constituição que regulamentasse a vida no vice-reinado. Em quinto lugar a Constituição podia declarar a independência absoluta dos reis da Espanha.

Tudo isso se baseava no grande princípio teológico dos direitos naturais do homem, de sua liberdade e de sua responsabilidade. As ambições dos homens desaparecem diante dos ideais que o complexo problema político daqueles momentos despertava no povo. $\mathrm{O}$ ator e autor de Maio foi o povo. Não foram minorias dirigentes nem grupos agitadores. O povo sabia que a Espanha estava perdida, que a América poderia cair em mãos estrangeiras, que o vice-rei não tinha mais direito de governar, que o povo devia resolver sòzinho seu destino e exigiu o govêrno por intermédio de seus representantes, a formação de uma Junta na qual não houvesse resíduos do antigo regime, mas homens novos que significassem uma renovação nas idéias e nas formas de govêrno. Para conseguir esta renovação, esta grande reforma do reino, só existia um caminho: o de alcançar o poder por meio do povo. E' preciso que nos coloquemos dentro daquela época e daqueles momentos para compreendermos a essência e o espírito desta luta política. Estava em jôgo a liberdade do homem, não como

\footnotetext{
(9). - Veja-se nosso livro Origenes desconocidos del 25 de Maio de 1810, Buenos Alres, 1960 .

(10). - Veja-se nosso livro Napoleón y la Independencia de América, Buenos Aires, 1955; e o de Ernesto J. Fitte, Castelli y Monteagudo, Buenos Aires, 1961.
} 
no tempo de Lutero e Calvino que se preocupavam com seu destino de além túmulo, agora se tratava de seu destino na terra, em que o sistema absolutista poderia oprimí-lo ainda por séculos .

Napoleão, com sua tirania, despertou os nacionalismos europeus, as ansias de liberdade, o romantismo, o individualismo de cada um e o direito que os povos e os homens tinham de governar-se por si mesmos. Diante dessa fome devoradora de liberalismo e de democracia levantavam-se fôrças retrógradas do Antigo Regime, esmagado pela Revolução Francesa e ressuscitado pelo napoleonismo. Era a luta da liberdade contra a anti-liberdade. Daí a ação secreta da maçonaria, cujos verdadeiros objetivos naquela época não são conhecidos com precisão. Daí o empenho de instalar Juntas populares de govêrno na Espanha e na América, desde o mês de maio de 1808 e os esforços dos que viam nessas Juntas a desagregação do império, a anarquia e a atomização do poder. O sistema das Juntas, adotado com entusiasmo pelo partido de Martín de Alzaga nos meados de 1808 fazia com que Belgrano, Castelli, Rodríguez, Poñe, Vieytes e outros dissessem, quando imploravam à infanta Carlota que viesse reinar no rio da Prata, que era um sistema anárquico, republicano, desengonçado e incendiário. Este sistema, que lançou as bases da nação argentina, estendeu-se até o Alto Perú e produziu as revoluções de Chuquisaca e La Paz. de 25 de maio e 16 de julho de 1809 . A propaganda partia do Rio da Prata e tanto alcançava o Alto Perú, quanto cidades como Santa Fé. Em novembro de 1809 tinham chegado panfletos nos quais se explicava que o povo tinha direito a

"elegir, nombrar y poner quién los gobierne, porque los pueblos hacen al rey y no el rey a los pueblos".

Parecem palavras dos comuneros Antequera e Mompó, no início do século XVIII. Falava-se da necessidade de formar uma Junta governamental e aconselhava-se que se pusessem em guarda para não se tornarem escravos (11) .

"de los herejes ingleses, franceses o del insufrible portugués"

O ideal das Juntas, criado por Martín de Alzaga, cumpriu sua trajetória até triunfar em maio de 1810 .

Por essas razões maio marca na história argentina uma transição profunda entre a colônia e a independência, entre o regime antigo de

(11). - Manuel M. Cervera, Don Francisco Antonio Candioti. Primer gobernador independiente en Santa Fé. 1743-1815, em Revista de la Junta de Estudios Históricos de Santa Fé, Santa Fé, 1948, tomo II, e Facundo A. Arco, Entre Rios en los Albores de la Revolución de Mayo, Paraná, 1960. 
govêrno à distância, da Península e o govêrno do povo pelo povo do país. Maio é o centro da história argentina de homens de cultura hispânica e cristã e o comêço da história argentina como nação. Maio representa o nascimento oficial do nacionalismo e do auto-govêrno da Argentina. Os homens de Maio tiveram uma consciência muito clara de sua responsabilidade e dos passos que davam. Não se enganavam nos seus temores e ilusões; mas, tampouco eram improvisadores, nem os ideais de Maio nasceram precisamente em Maio. Tinham suas raízes nos séculos e história hispano-americana e seu princípio na grande revolução de Madrí de 2 de maio de 1808 . E' por isso que quando os autores da revolução de $1^{\text {o }}$ de janeiro de 1809 foram submetidos a processo pelos maçons que rodeavam $\mathrm{Li}$ niers, um dos acusados, um jovem de 24 anos, Ciriaco Le Zica, afirmou que não merecia nenhum castigo porque tinham sido estabelecidas Juntas na Espanha e no México,

$$
\begin{aligned}
& \text { "que la Junta gubernativa no la tenía él por transtorno, sino } \\
& \text { por reforma", }
\end{aligned}
$$

e que era preciso conseguí-la ainda que fôsse pela fôrça das armas: resposta sensata e corajosa.

Antônio José Del Texo, o chefe da conspiração contra Saavedra declarou que em 1700, na época da Guerra de Sucessão na Espanha, tratava-se de uma luta de famílias com direitos iguais, mas em 1808 era um intruso que queria se apoderar da Espanha e que Liniers em uma proclamação tinha dito que deviam aceitar quem saisse triunfante. Por isso estava disposto a eliminar Liniers e Saavedra se fôssem contrários à formação de uma Junta como as da Espanha.

Era preciso salvar a terra de três grandes perigos internacionais - França, Inglaterra e Portugal - e de um grande perigo interno: o despotismo de Liniers. Por isso homens tão opostos em seus ideais íntimos e em suas ambicões ocultas. como os maçons que quiseram pouco antes entregar estas terras à Grã-Bretanha ou à infanta Carlota Joaquina e os anti-maçons de Alzaga e de Moreno que aspiravam à uma independência, lançaram-se igualmente à conquista do poder e conseguiram-no com a primeira Junta de 24 de Maio e com a segunda Junta de 25 de Maio.

Em 26 de maio os componentes da segunda Junta expressaram com suma claridade seus projetos e ideais ao comandante da fôrça naval britânica C. M. Fabian, aos tenentes Perkins e Ramsay e ao intérprete Fred Doyling. Fabian, em 29 de maio, escreveu uma entrevista com o chefe da esquadra, o almirante De Courcy, no Mutine. Afirmou que Saavedra lhe declara: 
"nosotros estamos sumamente agradecidos por la atención del Comandante En Jefe inglés... Pudiendo asegurarles que es la intención y deseo de esta Junta continuar la más firme alianza con el rey de Gran Bretaña para la defensa dos domínios de nuestro soberano Fernando VII".

\section{Em seguida, disse Castelli:}

"Esta Junta, los funcionarios públicos, el ejército y los habitantes, sin limitación, están dispuestos a hacer cuanto puedan para proteger los domínios de su amado rey Fernando VII; y están dispuestos y desean continuar en estricta alianza con Gran Bretaña y mostrar todo el favor posible y protección a los súbditos británicos los mismos sentimientos de alianza y amistad".

\section{E acrescentou:}

"Cuando España se hubo rendido, fue asunto de cotidiana esperanza, al tener noticia que toda ella había sido sojuzgada, no dejar este virreynato sin eficiente gobernante; por eso, este gobierno provisional se había formado con el objeto de preservar esta parte de América a su amado soberano; y que ellos esperaban estar reunidos en los mismos sentimientos de lealdad con las demás provincias españolas, y así, poder salvar los restos de la momarquía española, la cual podría ser capaz de, con el tiempo, de reconquistar a España de Francia. Ellos confiaban, por esto, que Gran Bretaña no solamente no invadiría estas provincias, sino que cooperaría en defenderlas de los enemigos externos, sea quien fuere, y continuar siendo hasta aquí lo que había sido: el más leal aliado de don Fernando VII (12).

Belgrano também estava presente. Era a primeira entrevista de um govêrno argentino com representantes de uma nação estrangeira. A Junta de 25 de Maio entrou em choque com os partidários do Conselho de Regência. Na nossa Historia del 25 de Mayo (13) historiamos a guerra civil da Junta com os defensores do Conselho de Regência de Cádiz que dominavam em Montevidéu. O reconhecimento do Conselho tinha sido quase geral na América. O Cabildo realizado em Assunção em 24 de julho de 1810 decidiu:

"proceder inmediatamente y sin disolverse esta Junta al reconocimiento y solemne jura del Supremo Consejo de Regência porque, en vista de los documentos leídos, no puede dudarse de su legítima instalación; guardar armoniosa correspondencia y frater-

(12). - Archivo General de la Nación. Donación Carlos Robertis. C. I. A. 5. Ne 5 - 1810. Veja-se Rituardo Piccirilli, San Martin y la politica de los pueblos, Buenos Aires, 1957.

(13). - Buenos Alres, 1960. 
ral amistad con la Junta provisional de Buenos Aires, suspendiendo todo reconocimento de superioridade en ella hasta tanto S. M. resuelva lo que sea de su soberano agrado...".

A Junta de Buenos Aires devia governar enquanto um Congresso - o Congresso que Alzaga tinha planejado em 1808 - não resolvesse o destino da história argentina. O agente português Guezzi escrevia em 17 de setembro de 1810:

"es claro que el Congreso no podrá ser considerado como la representación de un Estado soberano e independiente que forma una Constitución, pero como una comisión destinada a ejercer interinamente el poder ejecutivo hajo el auspicio de las leyes existentes $o$ que de nuevo emanen de la legítima representación nacional".

Este Congresso, sendo um dos objetivos da Junta de Maio, devia ser formado - conforme Alzaga tinha exposto antes - por representantes de todo o vice-reinado. Em 28 de setembro de 1810 lord Strangford informava o marquês de Wellesley de que

"até a província do Perú tinha enviado delegados ao Congresso geral que se realizara em primeiro de janeiro de 1811".

Tinham grande esperança no Congresso e a Gaceta da qual Moreno era diretor e redator, dava ao povo do vice-reinado as maiores notícias sôbre sua futura missão; mas a Junta de 25 de Maio trazia em si os germes da discórdia, os ódios dos homens, as negruras das consciências e os interêsses da política. O Congresso não se realizou por causa da ambição de Saavedra que fêz com que os delegados se incorporassem à Junta para esmagar Moreno. Os grandes projetos ficaram em suspenso. Só permanecia vivo o ideal de não cair nas mãos dos estrangeiros. Guezzi, numa carta ao conde de Linhares de 19 de janeiro de 1811, dizia:

"una circunstancia que V. E. no debe perder de vista es que los responsables de los motines de Buenos Aires no tienen propiamente ningún proyecto fijo de gobierno que los una y que el único principio de unión que los hace obrar es la determinación de no someterse a autoridades de orígen europeo o a las envidas de Europa".

Era o ideal de auto-govêrno, da auto-determinação dos povos, concretizado no sistema da Junta, que se elevava acima das paixões e lutava contra os partidários do Conselho de Regência .

Esta luta da Junta com os defensores do Conselho pode ser estudada com insuperável clareza na nota que Belgrano enviou ao general Cavañas, de Assunção, datada de 20 de fevereiro de 1811: 
"el orígen desta guerra es el aspirar los pueblos americanos a gozar de los derechos que tienen los de España. Será justo que prive de ellos al Paraguay un solo mandón que lo tiene esclavizado? $\mathrm{Y}$ será justo matarse unos a otros para disfrutar del goce de tán santos derechos?"

\section{O diálogo de Belgrano com o capelão do exército don José Agustín Molas é revelador:}

"Belgrano: Hermano mío: nosotros tenemos los mismos derechos de representar al soberano como tienen los pueblos de España, según declaró La Junta Central: pués si todos tenemos los mismos derechos, por qué no gobernamos nosotros mismos a nuestra patria cuando tenemos hombres tán doctos en nuestro propio país y no admitir yá a los europeos, que el más atrazado y miserable quiere vejarnos?

Padre Molas: Convengo con V. E. que nosotros tenemos los mismos derechos que los pueblos de España; por esta razón se instalaron Juntas en todos los reinos de ellos; pero con dependencia siempre de la Central o la Regencia; pero no para representar por si mismos sin referencia a esta, como quiere Buenos Aires... guintes:

Deixemos de lado outras frases do diálogo e vejamos as se-

Belgrano: ... pero por qué no quieren obedecer a la Junta cuándo ella es capital?

Padre Molas: Porque el pueblo de Buenos Aires no tiene autoridad por capital de subyugar a las demás provincias, sino únicamente representar sus derechos peculiares, como cada provincia los tiene y la autoridad del virrey, que se tomó al pueblo, no debe extenderse a las demás provincias, porque yá cesaba esta.

Belgrano: Un americano de las luces de V. M. no debe proferir tales expresiones, pués entonces quedaría el cuerpo político acéfalo.

Padre Molas: Deu mismo modo quedaría Buenos Aires respecto de la Regencia.

Belgrano: La Regencia yá no existe.

Padre Molas: Después veremos.

As posições eram irredutíveis. A doutrina jurídica de Maio era o govêrno do povo pelo povo e não admitia a dependência de um Conselho ilegal como o da Regência de Cádiz; mas no Paraguai pensavam de modo diferente. A 17 de junho de 1811 uma assembléia tomou resolução que a Junta de Assunção comunicou à de Buenos Aires em 20 de julho. A primeira dizia: 


\begin{abstract}
"que mientras no se forme el Congreso general de esta provincia se gobernará por si misma, sin que la Excelentísima Junta de esta ciudad pueda disponer y ejercer jurisdición sobre su forma de gobierno, régimen, administración ni otra alguna causa correspondiente a ellas".
\end{abstract}

Ficava suspenso realmente

"el reconocimiento de las cortes y Consejo de Regencia de España y de toda otra cualquiera representación de la autoridad suprema".

O Paraguai proclamava de fato sua independência em 17 de junho de 1811 antes da cidade de Caracas, que fêz o mesmo em 5 de julho daquele ano. Maio triunfou nos dias de suas duas Juntas; mas foi um esfôrço frustrado pelos choques ambiciosos de seus homens, pelas rebeldias dos caudilhos e pelo despotismo anti-argentino de Juán Manuel de Rosas. Por isso Maio se prolonga como um ideal inatingido, através dos sonhos dos proscritos, desde 1810 até a Constituição de 1853. Assim considerado, como símbolo de auto-govêrno do Congresso e da Constituição, Maio é o ideal constante da história argentina, seu fundamento e sua bússola, como a agulha imantada que salva as naus na escuridão e no fragor das tormentos. 